The Review of Politics 84 (2022), 1-24.

(C) The Author(s), 2021. Published by Cambridge University Press on behalf of University of Notre Dame. This is an Open Access article, distributed under the terms of the Creative Commons Attribution licence (https://creativecommons.org/ licenses/by/4.0/), which permits unrestricted re-use, distribution, and reproduction in any medium, provided the original work is properly cited.

doi:10.1017/S0034670521000711

\title{
The Rhetoric of Hobbes's Translation of Thucydides
}

\section{Chris Campbell}

\begin{abstract}
In several key passages in Thomas Hobbes's understudied translation of Thucydides's History of the Peloponnesian War, Hobbes's Pericles directs audiences to distrust rhetoric in favor of calculative self-interest, inward-focused affective states, and an epistemic reliance on sovereignty. Hobbes's own intervention via his translation of Thucydides involves similar rhetorical moves. By directing readers to learn from Thucydides, Hobbes conceals his own rhetorical appeals in favor of sovereignty while portraying rhetoric undermining sovereignty as manipulative, self-serving, and representative of the entire category of "rhetoric." Hobbes's double redescription of rhetoric is an important starting point for an early modern project: appeals that justify a desired political order are characterized as "right reason," "the law of nature," or "enlightenment," while rhetoric constituting solidarities or publics outside the desired order is condemned. Hobbes's contribution to this project theorizes rhetoric as a barrier to individual calculations of interest, placing a novel constraint on political life.
\end{abstract}

This article uncovers a series of surprising and unconventional renderings in Thomas Hobbes's translation of Thucydides's History of the Peloponnesian War. These renderings, which center on the figure of Pericles and, to a lesser extent, Alcibiades, are symptomatic of a sophisticated and original Hobbesian engagement with the relationship between rhetoric, political order, and self-interested individuals. Hobbes's Pericles directs his listeners to distrust rhetoricians engaged in political contestation in favor of their own calculative self-interest and inward-focused affective states, enabling them to reason

Chris Campbell recently received his PhD from the Department of Political Science at the University of Michigan, 505 South State Street, 6564 Haven Hall, Ann Arbor, MI 48109, USA (cacmpbl@umich.edu).

I am grateful to participants in the University of Michigan's Political Theory Workshop, participants at the Southern Political Science Association's 2019 conference, and the editor and anonymous reviewers at the Review of Politics. Thanks especially to Arlene Saxonhouse for her support in revising this article. 
consistently with Pericles's instruction. This portrayal sets Pericles up as a kind of sovereign educator, who temporarily enables Athenians to overcome the limits of collective deliberation through the individual calculation of selfinterest. Absent this educative role, Hobbes depicts Alcibiades as a failed sovereign, who offers characteristically Hobbesian psychological and political insights but cannot unite and educate a city.

Through his depiction of these figures, one a model, the other a warning, Hobbes takes on the role of a political educator, guiding readers to reason from the historical premises he has presented. This complex strategy allows Hobbes to model rhetorical appeals that reinforce sovereign authority and political order, while simultaneously portraying rhetoric that undermines political order as manipulative, self-serving, and representative of the entire category of "rhetoric." This rhetoric about rhetoric goes much further than the pattern in Leviathan that Bryan Garsten has described as "a rhetoric against rhetoric." ${ }^{1}$ Hobbes goes beyond directing his considerable persuasive skills toward frightening readers away from oratory as such, adopting a more complex strategy of persuading readers to discriminate between Hobbes's invented rhetorical categories.

Although there has been a recent wave of scholarly interest in Hobbes's translations of Thucydides and other works, this article offers the first close analysis of his translation choices that takes seriously the possibility of a substantive intervention into the text. It documents the scope and methods of Hobbes's intervention when he "decided to translate [Thucydides], in order to make him speak to the English about the need to avoid the rhetoricians whom they were at that time planning to consult." ${ }^{2}$ Where most recent scholarship focuses on three prefatory notes to the translation, I focus on the translation itself. Hobbes's renderings throughout the translation, while less explicit or argumentative than the notes, nonetheless comprise the "Thucydides" from whom Hobbes directed his readers to learn.

I analyze Hobbes's renderings of Thucydides in three key areas: Periclean rhetoric in the opening books of the History, Thucydides's commentary on Alcibiades, and Alcibiades's combined apologia and strategic advice to a Lacedaemonian audience. I identify clear through lines that match Hobbes's own philosophical commitments, and that differ from his renderings of

\footnotetext{
${ }^{1}$ Bryan Garsten, Saving Persuasion: A Defense of Rhetoric and Judgment (Cambridge, MA: Harvard University Press, 2009), 25. On the modes and sophistication of Hobbes's rhetorical appeals, see Quentin Skinner, Reason and Rhetoric in the Philosophy of Hobbes (Cambridge: Cambridge University Press, 1997); David Johnston, The Rhetoric of "Leviathan": Thomas Hobbes and the Politics of Cultural Transformation (Princeton: Princeton University Press, 1986); Ted H. Miller, Mortal Gods: Science, Politics, and the Humanist Ambitions of Thomas Hobbes (University Park: Pennsylvania State University Press, 2011); Timothy Raylor, Philosophy, Rhetoric, and Thomas Hobbes (Oxford: Oxford University Press, 2018).

${ }^{2}$ This translation of Hobbes's Latin prose autobiography, explaining the motive for his Thucydides, is found in Skinner, Reason and Rhetoric, 230.
} 
similar and even identical phrasing elsewhere in the History. These through lines evidence not only Hobbes's sympathies, but also a strategy of drawing readers toward those sympathies by emphasizing Pericles's wisdom, downplaying Alcibiades's flaws, and warning of the dangers of assemblies and rhetoricians. Finally, I connect the rhetoric of Hobbes's Pericles and Alcibiades to his broader engagement with the relationship between rhetoric, politics, and philosophy.

Hobbes's strategy in preparing and publishing the translation clarifies the role of eloquence in his political project. Rather than distinguishing between "good" or "bad" rhetorical techniques on the basis of the technique or of the substance of the appeals, Hobbes's critique of rhetoric targets the use of eloquence to extend or deepen a commonwealth's plurality, while reserving a role for practically any technique of persuasion that elevates and secures the authority of the sovereign.

\section{Situating Hobbes's Translation: Context, Commitments, and Methods}

As the first work Hobbes published under his own name, ${ }^{3}$ the translation of Thucydides has received a steady increase of scholarly attention as a resource for understanding his early intellectual development. While the translation itself remains almost entirely unexamined, scholars have drawn on three prefatory notes to the translation to characterize its role in Hobbes's broader intellectual product and in the early modern politics of translation. ${ }^{4}$ These notes

\footnotetext{
${ }^{3}$ Arlene Saxonhouse has argued that Hobbes authored much of the Horae Subsecivae, published anonymously in 1620 . Hobbes also wrote a Latin poem, De Mirabilibus Pecci, in the late 1620s, but this was not published until 1636. His translation of Thucydides is therefore the first published work he publicly claimed. See Arlene W. Saxonhouse, "Hobbes and the 'Horae Subsecivae,"' Polity 13, no. 4 (1981): 541-67; Noel B. Reynolds and Arlene W. Saxonhouse, eds., Three Discourses: A Critical Modern Edition of Newly Identified Work of the Young Hobbes (Chicago: University of Chicago Press, 1995), 3-21. For critical reviews of the attribution to Hobbes of the Horae, see John C. Fortier, "Hobbes and 'A Discourse of Laws': The Perils of Wordprint Analysis," Review of Politics 59, no. 4 (1997): 861-87; Noel Malcolm, Aspects of Hobbes (Oxford: Oxford University Press, 2004), 7. Raylor, Philosophy, Rhetoric, and Thomas Hobbes, 53-57, suggests that Hobbes played a "secretarial" role akin to a modern ghostwriter.

${ }^{4}$ Scholarly treatments of the translation as a robust political or philosophical work include Ioannis D. Evrigenis, "Hobbes's Thucydides," Journal of Military Ethics 5, no. 4 (2006): 303-16; Kinch Hoekstra, "Hobbes's Thucydides," in The Oxford Handbook of Hobbes, ed. A. P. Martinich and Kinch Hoekstra (Oxford: Oxford University Press, 2016); Timothy Burns, "Hobbes and Dionysius of Halicarnassus on Thucydides, Rhetoric and Political Life," Polis 31 (2014): 387; Raylor, Philosophy, Rhetoric, and Thomas Hobbes; Alicia Steinmetz, "Hobbes and the Politics of Translation," Political Theory 49, no. 3 (2021): 83-108. While none of these has closely examined the
} 
comprise a dedicatory letter to Hobbes's student William Cavendish, the third Earl of Devonshire, a preface titled "To the Readers" explaining the value of Thucydides's history and describing the supplementary maps and notes, and a biographical introduction titled "On the Life and History of Thucydides." Of these, the biographical introduction (henceforth "the Life") most clearly sets out Hobbes's understanding of Thucydides's life and concerns and his portrayal of Thucydides's relevance to English politics of the time.

I begin with a question of how fundamentally to approach the translation. Many analyses have relied on a set of binary possibilities: either Hobbes published, in Kinch Hoekstra's words, "a full and faithful translation," or he engaged in a wholesale transformation of "Thucydides into a thoroughgoing Hobbesian by selection and construal." ${ }^{5}$ The latter possibility overstates the case. ${ }^{6}$ The former, however, neglects the influence of translators' political and intellectual commitments on their choice of language, and the evidence of such influence on Hobbes's renderings of key passages of the History. Robin Sowerby's analysis takes Hobbes's renderings of Thucydides's speeches to be "deliberative rhetoric at its most severely analytic and persuasive," and argues that the translation reflects a broader Hobbesian practice of "employing the techniques of eloquence in the service of science." ${ }^{7}$ Sowerby dismisses the possibility "of Hobbes' translation seriously misrepresenting the Greek," on the basis that "his intellectual integrity would not have allowed him to appropriate Thucydides' text to support some thesis of his own." ${ }^{8}$

More recent studies have complicated this account. Emily Greenwood's rich analysis of the methods and stylistic choices of Thucydides's translators has revealed a wide range in many of these choices, often connected to the cultural and political resources on which the different translators drew. ${ }^{9}$

translation, I am indebted to their analysis of its context and Hobbes's possible purposes in preparing and publishing the translation.

${ }^{5}$ Hoekstra, "Hobbes's Thucydides," 549.

${ }^{6}$ Hobbes's translation of a highly condensed version of Aristotle's Rhetoric probably does count as such a drastic transformation of the original. My reading of this translation as substantially revising and undermining the perspective of the original text owes to Thomas Sorell, "Hobbes's UnAristotelian Political Rhetoric," Philosophy $\mathcal{E}$ Rhetoric 23, no. 2 (1990): 97-98, 103-6; Ned O'Gorman, "Hobbes, Desire, and the Democratization of Rhetoric," Advances in the History of Rhetoric 16, no.1 (2013): 4-8. See also Don Paul Abbott, "'Eloquence is Power': Hobbes on the Use and Abuse of Rhetoric," Rhetorica 32, no. 4 (2014): 386-411; Quentin Skinner, Hobbes and Republican Liberty (Cambridge: Cambridge University Press, 2008), 5n20.

${ }^{7}$ Robin Sowerby, "Thomas Hobbes's Translation of Thucydides," Translation and Literature 7, no. 2 (1998): 167, 165.

${ }^{8}$ Ibid., 157.

${ }^{9}$ Emily Greenwood, "On Translating Thucydides," in A Handbook to the Reception of Thucydides, ed. Christine Lee and Neville Morley (Malden, MA: Wiley, 2015), 91-121. 
Greenwood's choices in her version of the horrific slaughter of Athenian forces at Syracuse draw on the horrors of trench warfare in the First World War, where she specifically references the work of Wilfred Owen. ${ }^{10}$ Henry Jones has identified a systematic political intervention in Benjamin Jowett's translation of Thucydides, emphasizing the role of leaders in democratic cities, in keeping with the profoundly pessimistic assessment of the democratic masses' capacity for judgment that Jowett expressed in his private correspondence. ${ }^{11}$ While most of her treatment of the Thucydides translation focuses on the frontispiece and prefatory materials, Alicia Steinmetz has pointed out that Hobbes's translation at times "gives the specific impression that words such as 'boldness' and 'modesty' merely expressed the subjective passions of those who used them." ${ }^{\prime 12}$ Most strikingly, Alexandra Lianeri has argued that the hostility towards democratic governance that pervaded Hobbes's engagement with Thucydides shaped elite reception of classical texts and theories of collective governance for the following two centuries. ${ }^{13}$

Each of these engagements with the politics of translating Thucydides helpfully identifies strategic interventions in the act of translation, without attempting to evaluate whether these interventions cross a threshold of impugning the translator's integrity or faithfulness. This scholarly nuance is particularly appropriate when examining translations of Thucydides. Thucydides's own remarks at the beginning of the History are worth quoting: "I made each of the speakers say what it seemed to me the various occasions demanded of them, keeping as closely as possible to the overall intention of what they really said." ${ }^{14}$ Scholars differ as to the precision with which Thucydides adhered to what was really said, the balance between the original speakers' intent and Thucydides's judgment of the rhetorical necessities the speakers faced, the implications of Thucydides's composition

${ }^{10}$ Ibid., 114. This version sharply differs from nineteenth- and early twentiethcentury translations of Pericles's funeral oration, which verge on overt jingoism. Sowerby, "Hobbes's Translation," 163-64, describes these translations as "lyrically patriotic," which is perhaps too sympathetic.

${ }^{11}$ Henry Jones, "Jowett's Thucydides: A Corpus-Based Analysis of Translation as Political Intervention," Translation Studies 13, no. 3 (2020): 333-51.

${ }^{12}$ Steinmetz, "Hobbes and the Politics of Translation," 9-10. Cf. Raylor's characterization of Hobbes's rendering of Thucydides's method of recounting speeches as a "rather curious mistranslation." Raylor, Philosophy, Rhetoric, and Thomas Hobbes, 82.

${ }^{13}$ Alexandra Lianeri, "Translation and the Establishment of Liberal Democracy in Nineteenth Century England: Constructing the Political as an Interpretative Act," in Translation and Power, ed. Maria Tymoczko and Edwin Gentzler (Amherst: University of Massachusetts Press, 2002), 1-24.

${ }^{14}$ Thucydides, Historiae in Two Volumes (Oxford: Oxford University Press, 1842), 1.22.1, available at Perseus Digital Library. Translations are my own, except where otherwise stated. 
of key speeches for his historical project, and many further questions that this passage raises. ${ }^{15}$

The complexities of Thucydides's own presentation of these speeches, and the tensions he faced in presenting these speeches, make it inevitable that translators would differ substantially over correct renderings, and that these differences might well communicate something important about the translators' commitments and agendas. As the first person to translate Thucydides into English from the original Greek, Hobbes had a rare opportunity to present an influential rendering of Thucydides that was consistent with Hobbes's own commitments and agenda.

As noted, the scholarship on this text has focused mostly on Hobbes's prefatory comments, with occasional general analyses of the translation's tone or references to relatively isolated choices of terms. But Hobbes might have had a more specific idea of how readers should learn from Thucydides. We should not expect any positive lessons from "the demagogues" whose "crossing of each other's counsels" resulted in "the damage of the public." ${ }^{16}$ Hobbes would have no interest in contemporary scholarship on the lessons of Diodotus, for example, because in his view, the Mytilene debate is an example of undisciplined glory-seeking squabbles over the approval of the multitude. ${ }^{17}$ Similarly, Hobbes repeatedly (and reasonably) centers

\footnotetext{
${ }^{15}$ Recent scholarship in which these questions are active and productive includes Sara Forsdyke, "Thucydides' Historical Method," Antonis Tsakmakis, "Speeches," and Kinch Hoekstra and Mark Fisher, "Thucydides and the Politics of Necessity," all in The Oxford Handbook of Thucydides, ed. Sara Forsdyke, Edith Foster, and Ryan Balot (Oxford: Oxford University Press, 2017); Gottfried Mader, "Demagogic Style and Historical Method: Locating Cleon's Mytilenean Rhetoric," Rhetorica 35, no. 1 (2017): 1-23; Odysseus Makridis, "The Austere Demagogue: Thucydides on the Uses and Abuses of Periclean Rhetoric," Atlantic Journal of Communication 19 (2011): 268-84; C. M. Fauber, "Hermocrates and Thucydides: Rhetoric, Policy, and the Speeches in Thucydides' 'History,'” Illinois Classical Studies 26 (2001): 37-51.

${ }^{16}$ Hobbes, "On the Life and History of Thucydides," in The English Works of Thomas Hobbes of Malmesbury: Thucydides (London: Bohn, 1843).

${ }^{17}$ Recent insights that Hobbes would disregard may be found in Laurie M. Johnson, Thucydides, Hobbes, and the Interpretation of Realism (DeKalb: Northern Illinois University Press, 1993), 104-16; Clifford Orwin, The Humanity of Thucydides (Princeton: Princeton University Press, 1994), 146-62; Arlene W. Saxonhouse, Athenian Democracy: Modern Mythmakers and Ancient Theorists (Notre Dame, IN: University of Notre Dame Press, 1996), 72, 75-78; Susan Bickford, "Emotion Talk and Political Judgment," Journal of Politics 73, no. 4 (2011): 1025-37; Joel Alden Schlosser, "'Hope, Danger's Comforter': Thucydides, Hope, Politics," Journal of Politics 75, no. 1 (2012): 169-82; Edward M. Harris, "How to Address the Athenian Assembly: Rhetoric and Political Tactics in the Debate about Mytilene (Thuc. 3.3750)," Classical Quarterly, n.s., 63, no. 1 (2013): 94-109. While these works offer widely different perspectives, all read Thucydides as complicating (or outright rejecting) "realist" accounts of politics between cities, portraying figures like Diodotus as genuinely insightful, or both.
} 
Thucydides's narrative and the political opinions that he attributes to Thucydides about Athens, while presenting Thucydides as anticipating and rejecting Aristotelian political typologies. While Thucydides "least of all liked the democracy" and had no patience for "the authority of the few," he most "commendeth" the Athenian government "when Peisistratus reigned, (saving that it was an usurped power), and when in the beginning of the war it was democratical in name, but in effect monarchical under Pericles." ${ }^{18}$

This says a great deal more than might be apparent. Those familiar with Aristotle's political typologies, as many of Hobbes's readers were, would have noticed that Hobbes reduces Peisistratus's tyranny to the specific fact of "usurped power" and otherwise collapses Peisistratus's and Pericles's rule into examples of monarchy. In keeping with his own royalism, Hobbes offers only the barest lip service to Athenian "mixed" government under the Five Thousand, immediately after sharp attacks on both democracy and oligarchy and immediately before emphasizing Thucydides's sympathies for "the regal government." Athens is the city of primary interest to the reader, Hobbes makes clear, and of the Athenian leaders and political figures, the only one to receive any explicit praise in the prefatory materials is Pericles. Timothy Raylor accurately summarizes the tone of the prefatory comments, as well as the marginal notes to the translation, when he comments that "with the sole exception of Pericles, there is no place in Hobbes's Thucydides for the honest practitioner of public eloquence." ${ }^{19}$

In the "Life" - his biographical introduction to the translation-Hobbes directs attention to Pericles's role in the History, both explicitly and by contrast with the competing Athenian rhetoricians whom Hobbes connects to Hobbes's parliamentarian nemeses. In discussing Thucydides's early life and education, Hobbes emphasizes the fact that Thucydides's teacher in philosophy also taught Socrates and Pericles. Hobbes's comment that "in those days it was impossible for any man to give good and profitable counsel for the commonwealth, and not incur the displeasure of the people" clearly refers to the end of Pericles's career. His explanation of Thucydides's preference for history over direct political engagement in terms of Pericles's eventual loss of support ties the two figures together. ${ }^{20}$ Similarly, Hobbes emphasizes Cleon's responsibility for banishing Thucydides. Since Cleon began his political career as one of Pericles's foremost political opponents and quite possibly the instigator of Pericles's prosecution for misusing public funds, this again emphasizes a biographical connection between Thucydides and Pericles. ${ }^{21}$ I begin my examination of Hobbes's translation

\footnotetext{
${ }^{18}$ Hobbes, “Life," xvii.

${ }^{19}$ Raylor, Philosophy, Rhetoric, and Thomas Hobbes, 81.

${ }^{20}$ Hobbes, "Life," xvi.

${ }^{21}$ Plutarch mentions Cleon as the first of three possible prosecutors of Pericles identified by historians of the fourth century BCE. Plutarch, Pericles 35.3, in Lives, trans. Bernadotte Perrin, vol. 3 (Cambridge, MA: Harvard University Press, 1916).
} 
with his treatment of Pericles, who stands as the kind of sovereign monarchic figure who Hobbes could reasonably have endorsed as a guide to the fractious and competing Athenian multitudes. Alcibiades enters the reading later, but not because Hobbes ever explicitly praises Alcibiades in the prefatory notes. Instead, during the period of political deformation after Pericles's death, Hobbes presents Alcibiades as a tragic parallel to the former leader of the Athenians.

\section{Periclean Rhetoric and Self-Interest}

Pericles's funeral oration is hardly the first place in which a contemporary reader would look for a political vision of calculation and self-interest. After all, the final section of the speech begins in roughly the following way in practically all recent renderings:

Do not consider mere arguments about profit. Anyone can wax on about these, even though you yourselves know no less than he does about the benefits to be gained by bravely resisting the enemy. Instead, gaze daily on the city's real power, and become her lovers. ${ }^{22}$

Here, on the other hand, is Hobbes:

And for you that remain, you may pray for a safer fortune, but you ought not to be less venturously minded against the enemy, not weighing the profit by an oration only, which any man amplifying may recount to you that know as well as he the many commodities that arise by fighting valiantly against your enemies, but contemplating the power of the city in the actions of the same from day to day performed and thereby becoming enamoured of it. $^{23}$

Hobbes's rendering shifts the passage's tone in two important ways. First, his Pericles emphasizes the practical calculation of power and interest-" the many commodities that arise by fighting valiantly," "the power of the city" - over appeals to affect and the implication of an erastic relationship between citizen and city. Second, Hobbes has Pericles frame this calculation not in terms of collective deliberation, or even as an instruction for the audience to accept Pericles's judgment as their own, but as a call for individuals to cultivate a capacity for their own calculation of their interests: "not weighing

${ }^{22}$ Thucydides 2.43.1. For consistency with other recent translations, compare S. Sara Monoson, Plato's Democratic Entanglements: Athenian Politics and the Practice of Philosophy (Princeton: Princeton University Press, 2000), 68; Martin Hammond, trans., The Peloponnesian War (Oxford: Oxford University Press, 2009); Jeremy Mynott, trans., The War of the Peloponnesians and the Athenians (Cambridge: Cambridge University Press, 2013). On the significance of Pericles's speech as a vision of Athenian democracy, see Ryan Balot, Courage in the Democratic Polis: Ideology and Critique in Classical Athens (Oxford: Oxford University Press, 2014), 25-46.

${ }^{23}$ Hobbes, English Works: Thucydides, 2.43. Emphasis is mine. 
the profit by an oration only... but contemplating"; "you... know as well as he [an 'amplifying' orator]." Hobbes sets up Pericles as an educator of both the Athenian audience and Hobbes's own readers, directing both to abandon the counsels of orators in favor of calmly calculating what actions advance the self-interest of individual audience members.

As Sara Monoson has argued, Pericles's appeal carried powerful cultural connotations that combined an invocation of citizens' need for the city with an appeal to make difficult choices on the city's behalf. ${ }^{24}$ By identifying service to the city with the role of erastēs, Pericles draws on the norms of Athenian masculinity in a way that appeals to all male citizens and emphasizes the importance of political unity. Since Athenian masculinity (andreia, which literally meant "manliness" but was the most common term in Attic Greek for "courage") required a daring willingness to expose oneself to danger, Pericles's appeal is particularly appropriate for his wartime agenda. Finally, and crucially for Monoson's reading, Pericles's reference to the erastic relationship emphasizes "relations of mutuality" that both offer a unique vision of individual contributions to a healthy polis and suggest a sort of balance and self-restraint that would have advanced Pericles's policy of limited "defensive" war. This reading also fits with the prior sentence, in which Pericles wishes to direct the audience's attention away from someone who would merely speak of the "advantages" to be procured from defending the city in war.

Hobbes's rendering, however, carries very different political implications. Hobbes begins to deemphasize the erotic and affective ties in this appeal with the highly unusual choice to translate theomenous ("gazing on") as "contemplating," which in a similar participial form would be theōroumenous. While the latter word-in Attic Greek-derives from the former, the two are distinct and there is no textual basis for conflating them. It is unlikely that Hobbes simply missed the standard translation here. As Sowerby has argued, Hobbes's treatment of the Greek is strikingly competent on both literary and stylistic levels, particularly compared to previous translations that had relied overmuch on Latin versions of the text. ${ }^{25}$ It is also implausible to read "contemplating" as carrying the normal force of the Greek term. While there is evidence of a usage of "contemplate" in a visual sense in English from the sixteenth century onward, even that sense of the word carries an abstracted and often intellectual force. ${ }^{26}$ Elsewhere in the History, Hobbes's uses of the noun form "contemplation" emphasize a calculative consideration of factors that ought to inform a decision or action. To the extent that contemplation involves affective factors, these affects are treated as

\footnotetext{
${ }^{24}$ Monoson, Plato's Democratic Entanglements, 68-90.

${ }^{25}$ Sowerby, "Hobbes's Translation," 147, 149-153.

${ }^{26}$ For example, the Oxford English Dictionary (s.v.) cites uses of "contemplate" to describe astronomical observations (1533) and God's consideration of the works of creation on the seventh day (1605); the latter, by Francis Bacon.
} 
data for calculation, rather than themselves action guiding. ${ }^{27}$ Similarly, Hobbes's uses of the verb "contemplate" elsewhere in his work are strictly intellectual. ${ }^{28}$ One of Leviathan's most famous passages has people "taking pleasure in contemplating their own power in the acts of conquest, which they pursue farther than their security requires." ${ }^{29}$ Here, the misaligned object of calculation - the libidinous attachment to one's own power, which distracts from seeking peace-leads to the war of everyone against everyone in the state of nature, where Pericles's audience would have been well directed to contemplate the city's power, and therefore to restrain themselves and follow Pericles's war policy.

We thus have a clear pattern of usage in Hobbes's terminology that points to Pericles telling his listeners to carefully and coldly consider the city's power and the effect of that power on their own well-being, and therefore to devote their energy to securing the city that protects their own lives and flourishing. Since theōmenous, as Monoson has pointed out, carries in this context an erotic connotation, Hobbes intellectualizes Pericles's appeal. Hobbes's rendering of ergōi as "in the actions of the same," rather than the idiomatic "real" or "genuine" that the reference to "deeds" generally suggested in Athenian rhetoric, tends also to suggest a cold analysis of Athens's capabilities. And similarly, the unconventional attachment of "daily" to Athens's actions rather than to the act of beholding the city suggests, in Hobbes's rendering, that the audience need only make up their minds about the city's worth, rather than making a habit of devotion to the city. This tendency to intellectualize and deeroticize Pericles's appeal continues at the end of the phrase, rendered by Hobbes as "becoming enamoured of it" rather than "becoming her lovers." Here, Hobbes neuters the feminine adjective autēn, further disembodying Pericles's appeal and creating intellectual distance between the audience and the object of their commitment.

At the same time, Hobbes individualizes the target of Pericles's instruction by emphasizing a call for citizens to displace orators' appeals in favor of their own calculative contemplation. My translation above, like many other translations since Hobbes's, contrasts the possibility of making lengthy calculations about the self-interested reasons for fighting for Athens with Pericles's appeal

${ }^{27}$ Cleon: "in contemplation of [tēi gnōmēi, "keeping in mind"] what you were near suffering . . . requite them now accordingly" (Hobbes, English Works: Thucydides, 3.40.7). The Plataean delegates urge Sparta to exercise "a moderate compassion" on their city "in contemplation [katanoountas] not only of the greatness of the punishment but also of who we are that must suffer and of the uncertainty where calamity may light, and that undeservedly" (3.59.1). Hermocrates: "In contemplation [gnontas] whereof, we ought . . . to return again into amity" (4.61.2).

${ }^{28}$ Hobbes, in the preface to De Cive: "Other [pre-Socratic] philosophers in the mean time, to the advantage of mankind, did contemplate the faces, and motions of things; others, without disadvantage, their natures, and causes." Hobbes, De Cive (London: Royston, 1651).

${ }^{29}$ Thomas Hobbes, Leviathan, ed. Edwin Curley (Indianapolis, IN: Hackett, 1994), 75. 
to create embodied and erotic ties to the city's well-being. ${ }^{30}$ I see Pericles directing the audience's attention to the city's power and imperial excellence in the hope that these will instill affective ties in the audience, beyond the simple calculation that a Peloponnesian victory would probably be bad for most individual Athenians. Hobbes, instead of contrasting self-interested calculation with a focus on collective excellence, contrasts the choice of personally calculating the benefits of attaching oneself to a powerful entity likely to win its current conflicts with trusting an orator's assessment of these benefits. In other words, Hobbes's translation has Pericles's funeral oration reminding his audience of truths that they could determine for themselves and urging the audience not to trust others to do that work for them. For Hobbes, properly calculating self-interest requires a distrust of anyone who would tell an audience to accept something without properly demonstrating it.

One might suppose that these renderings are characteristic of Hobbes's broader style, instead of a focused approach to translating Periclean rhetoric. Sowerby has argued that his adoption of "rhetorical restraint" in translating Thucydides, in which "the appeal is always primarily to the intellect," points the way to a Hobbesian project of "employing the techniques of eloquence in the service of science." ${ }^{31}$ Sowerby's conclusion, provided one substitutes for "science" a term more appropriate to Hobbes's commitments in the late 1620s, is not far off the mark. But Sowerby's focus on the funeral oration obscures the inconsistency in Hobbes's preference for calculative, intellectual phrasing, which is not uniformly expressed in key orations from the History. For example, Hobbes presents Cleon's diatribe against Mytilene in its full polemical color. Cleon accuses his listeners of "becoming softened" (malakizesthai) without earning any "favors" (charin) from their allies. ${ }^{32}$ While this language can be read as sexual innuendo in English, their force in Attic Greek is considerably more explicit. Hobbes preserves this in his rendering of Cleon's speech, in which the ekklessia "are softened thus to the danger of the commonwealth not to the winning of the affections of your confederates." This already differs from the way Hobbes intellectualizes the erotic metaphor that I have discussed above, from the end of Pericles's funeral oration. But in fact, Hobbes translates the very same Greek word differently when he encounters it in the funeral oration.

Pericles celebrates Athenians' moderation as follows: "For we love beauty, yet with simple tastes, and wisdom, yet without softness." ${ }^{33}$ Here, Pericles is responding to a critique of Athenian norms, on which an excessive focus on art and philosophy could leave them unable to compete with the austere physical training of Spartan hoplites. The crucial point for Pericles is that a

${ }^{30}$ Cf. Benjamin Jowett, trans., Thucydides Translated into English (Oxford: Clarendon, 1881); Richard Crawley, trans., History of the Peloponnesian War (London: Dent, 1910); Hammond, Peloponnesian War; Mynott, War of the Peloponnesians and the Athenians.

${ }^{31}$ Sowerby, "Hobbes's Translation," 162-65.

${ }^{32}$ Thuc. 3.37.

${ }^{33}$ Thuc. 2.40. Jowett translates malakias as "loss of manliness"; Mynott as "effete." 
robust intellectual life does not trade off with physical courage or competence. As elsewhere in Pericles's speeches, Hobbes's rendering entirely changes the force of the metaphor when the last phrase becomes "yet without mollification of the mind." Hobbes not only removes any hint of the sexual metaphor involved, but also suggests that the moderation Pericles is describing is between mental exercise and mental exhaustion, rather than between wisdom and strength. The key virtue that Periclean rhetoric encourages, on Hobbes's interpretation, is mental flexibility that allows individuals to rationally determine what is in their own self-interest, which produces military and civic strength insofar as such strength protects the interests of individuals.

An important consequence of Hobbes's Periclean rhetoric is the proper situating of honor-seeking and glory-seeking behavior within the wartime polis. ${ }^{34}$ Given Hobbes's tendency to suppress erotic and affective aspects of Pericles's rhetorical appeals, it is striking that references to honor and glory pervade the passage: being "sensible of dishonour" aided the "valiant men" who died to secure the city's power; their contribution was "most honourable"; "their glory is laid up upon all occasions both of speech and action to be remembered forever. ${ }^{\prime 35}$ Far from warning against pursuing glory in wartime, Hobbes's Pericles specifically urges his listeners to imitate these glorious predecessors. It turns out, however, that the sort of glory that Pericles's listeners have to look forward to is quite consistent with the broader objectives of calculative self-interest and political order. As recent commentators have pointed out, Hobbes's assessment that a certain level of glory seeking is characteristic of humans, owing to the connection between honor and power, is tempered by two other considerations: the possibility of educating individuals about the desirable kinds of glory through the sovereign's instruction, and the possibility of aweing them and curbing their ambitions through the power of the commonwealth. ${ }^{36}$

Each of these considerations appears in the rhetoric of Hobbes's Pericles. The only kind of honor or glory worth seeking, on an individual level, is dependent on the city's victory and prosperity. It is not only the case that glory and honor obtain only because of the judgments of others, but also that martial glory and honor depend entirely on the individual's contribution to collective success. Where the competition of orators for the multitude's affections brings civic danger with success, the efforts of soldiers, Hobbes's Pericles makes clear, bring the city's salvation. As a result, Hobbes has Pericles draw on what Hobbes and Thucydides agree to be the fundamental

\footnotetext{
${ }^{34}$ I am grateful to an anonymous reviewer for pressing me on this point.

${ }^{35}$ Hobbes, English Works: Thucydides, 2.43.

${ }^{36}$ Cf. Gabriella Slomp, "Hobbes on Glory and Civil Strife," in The Cambridge Companion to Hobbes's "Leviathan," ed. Patricia Springborg (Cambridge: Cambridge University Press, 2007), 181-98; Tracy B. Strong, "Glory and the Law in Hobbes," European Journal of Political Theory 16, no. 1 (2017): 61-76.
} 
human desire for honor, and indeed use that desire as a part of the self-interest that the listeners must calculate.

With the central Hobbesian virtue-the cultivated capacity for self-interested calculation - in mind, a brief return to the beginning of this section is in order. The cumulative effect of Hobbes's rendering of these passages of the funeral oration is to quiet the distinction between individual profit and the collective good of the city, while introducing a distinction between being guided by an "oration" that lacks epistemic authority and being guided by Pericles's advice to examine the effects of the city's power on the individual's well-being. Hobbes's Pericles advises his listeners to disregard rhetoricians, on the basis that rhetoricians possess no worthwhile knowledge that the listeners, "who know as well as [they]" the profits of victory, lack. This is not self-deprecation. Pericles, in Hobbes's presentation, is protecting his political leadership by speaking directly to the people while simultaneously isolating them from those rhetoricians, such as Cleon, who would undermine it. Put another way, Hobbes has Pericles draw a distinction between "rhetoric," which Pericles's rivals use while seeking power and glory, and Pericles's instruction of the audience in the principles of right reason. This highly original distinction connects rhetoric with domination, and the monarchic instruction of Pericles with sovereign guidance for the calculative and rational individual subject.

\section{Periclean Rhetoric and Civic Unity}

While the former connection proved very productive for Hobbes's project, and for the projects of theorists he influenced, the latter connection between rational and calculative self-interest, monarchic instruction, and civic order is highly unstable. Hobbes's Pericles strengthens this connection by emphasizing individual calculation as an essentially political act, as well as by arguing that individual self-interest can only be advanced through political unity. These elements are especially clear elsewhere in the History, when Pericles encourages the Athenians to choose war over retrenchment at the end of book 1 and when he defends his war policy shortly before his death late in book 2. In these passages, Hobbes finds powerful resources for appeals to self-interest while emphasizing the role of collective power in securing self-interested citizens from external threats. For example, Hobbes repeatedly renders Pericles's references to slavery as an alternative to Athens's continued dominance in terms of becoming "subject." The first instance involves a refusal to comply with Peloponnesian demands, on the basis that "a great and a little claim imposed by equals upon their neighbours before judgment by way of command hath one and the same virtue, to make subject [doulōsin $].{ }^{\prime 37}$ At stake here is a

${ }^{37}$ Hobbes, English Works: Thucydides, 1.141. This is not simply an idiosyncrasy; Hobbes translates the same root elsewhere in terms of slavery. 
move from a very personal threat-Pericles telling the Athenians that they must choose war or slavery - to the threat of the status of "subject," which is an exclusively political concept in Hobbes's vocabulary. The audience members are therefore to fear losing their collective political independence. This allows Hobbes to create a narrative parallel, where one might not otherwise exist, between Pericles warning the Athenians that the Peloponnesians intend to "make [them] subject" at 1.141 and Pericles describing the choice to end the war as a choice to "be subject" (hupakousai, literally to "give ear to" the enemy) at 2.61 .

One can imagine a very different narrative parallel in the original text's depiction of Pericles's claims. Thucydides does depict Pericles saying (at 1.141) that the Spartans seek to enslave the Athenians, but has Pericles omit the stronger verb at 2.61 in favor of hupakousai when describing the cost of defeat and retrenchment. Instead, its only appearance in the later passage comes in Pericles's claim that the Athenians' spirits are brought low by their recent military reverses because "that which is unforeseen and unexpected and furthest outside calculation enslaves the mind." ${ }^{\prime 38}$ Reading the speeches together this way would suggest that in the earlier speech, Pericles is attempting to outrage his audience at the thought of being enslaved, as part of a broader strategy to gain support for war. In the later speech, his audience is already angry at him and he uses calmer language to cool them down, cause them to reflect on what he sees as the basic soundness of his war strategy, and retain his political influence in Athens. A note of petulance shows through in Pericles's snappish accusation that his listeners' minds are enslaved, as well as his repeated reminders to the Athenians that they voted for the war measures they now disapprove of. One could read these passages as tragically exposing the flaws in Pericles's audience, as Thucydides seems to when reflecting on Pericles's life in the subsequent passage. Hobbes's rendering goes beyond this critical aspect by presenting Pericles as a voice of reason at all times, flattening the variations in tone, affect, and vocabulary across Pericles's speeches. As a result, the Athenian audience becomes more inconsistent and unreasonable than would otherwise be the case.

Hobbes's rendering sharpens Pericles's discussion of collective power and its challenges. By phrasing the threats to Athens in terms of threats to it as a political unit, Hobbes's Pericles makes collective action seem easier, or at least necessary, for his fellow Athenians while heightening the perceived difficulty of collective action among Athens's enemies. Pericles identifies a series of barriers to the Peloponnesians' effective collective struggle against Athens. They are internally divided, "not having one and the same counsel . . . and having equality of vote and being of several races." They "can speedily perform nothing upon the occasion" and, with different interests-"some will desire to take revenge upon the enemy and others to have their estates

\footnotetext{
${ }^{38}$ Thuc. 2.61. Hobbes: "For that which is sudden and unexpected and contrary to what one hath deliberated enslaveth the spirit."
} 
least wasted" - they will be ineffective on the rare occasions that they do meet to plan strategy. Hobbes's Pericles sums up the problems of coordinating action among self-interested allies by offering an early formulation of the collective action problem: "everyone supposeth that his own neglect of the common estate can do little hurt and that it will be the care of somebody else to look to that for his own good, not observing how by these thoughts of everyone in several the common business is jointly ruined." ${ }^{39}$

This criticism of the Peloponnesian alliance ought to apply even more severely, on Hobbes's terms, to the Athenians themselves. After all, the Athenians have many political counselors, have equal voting rights among thousands or perhaps tens of thousands of citizens, and disagree on the amount of damage to their "estates" that they are willing to tolerate. The crucial link that makes the Athenians' deliberations temporarily less disastrous than Pericles expects their enemies' deliberations to be is, in Hobbes's presentation, Pericles himself. Pericles is the only source for the quintessentially Hobbesian insight that "a private man, though in good estate, if his country come to ruin, must of necessity be ruined with it; whereas he that miscarrieth in a flourishing commonwealth shall much more easily be preserved. ${ }^{\prime 40}$ As a sovereign educator, Hobbes's Pericles unites Athenians' disparate interests by convincing them that those interests can only be achieved through a continued commitment to the Athenian commonwealth.

Rendering Pericles's rhetoric as an appeal to calculative self-interest means that political unity depends on a stable relationship between self-interest and the commonwealth. Hobbes's renderings of Periclean rhetoric reinforce this relationship. Pericles consistently disciplines Athenians' sense of fear, teaching them to avoid that which most threatens their well-being and to manage risk rationally. The worst evil an Athenian can face, Hobbes's Pericles instructs them, is the disintegration of the city that allows them to live flourishing lives. Only the city's power stands between Pericles's listeners and destruction. Their courageous service to the city is therefore an act of rational self-defense, and they should look to the threat of political subjugation, which would remove the commonwealth's aegis from above them, as a guide for policy.

\section{Fear, Self-Interest, and Alcibiades's Hobbesian Insights}

For Hobbes, any politician without Pericles's manifest superiority is sufficiently equal to other politicians that a struggle for public preeminence is risky and even hubristic. ${ }^{41}$ As a result, in his rendering, Alcibiades emerges

\footnotetext{
${ }^{39}$ Hobbes, English Works: Thucydides, 1.141.

${ }^{40}$ Hobbes, English Works: Thucydides, 2.60.

${ }^{41}$ Cf. Hobbes's argument from "natural" equality in Leviathan 13.1-2. Hobbes, Leviathan, ed. Curley, 74-75.
} 
as a unique character in Athenian politics after Pericles's demise. While Hobbes does not explicitly condone Alcibiades's brazen self-centeredness, it nonetheless allows for pithy expressions of self-interest outside the context of what Hobbes calls Pericles's monarchy. Hobbes moderates Thucydides's criticism of Alcibiades from the latter's first appearance in the History by distinguishing between the masses' justified distaste for Alcibiades's extravagance and personal irresponsibility and what Hobbes portrays as their unjustified fear that Alcibiades desired a tyrant's power and prestige. Later in the translation, Alcibiades takes a position of epistemic authority before a Spartan audience that resembles the authority Hobbes's Pericles held over the Athenians. In this position, Alcibiades turns out to offer a strikingly Hobbesian perspective on fear, self-interest, and military psychology.

Early in the debates over the Sicilian expedition, where Thucydides introduces Alcibiades, both Alcibiades's great talents and his essential untrustworthiness emerge:

The masses feared him on account of the magnitude [megethos], both of the lawlessness [paranomias] of his way of life, and the ambition [dianoias] that guided everything he did, as if he desired a tyranny, and so set themselves against him. Because of this, although he managed the war forcefully [ kratista] on behalf of the demos, his private habits offended each of them and they turned to others, and thus, not long after, ruined the city. ${ }^{42}$

While Thucydides believes Alcibiades's generalship offered Athens' best chances at an aggressive war policy, he also treats the Athenians' grievances as legitimate. Thucydides portrays Alcibiades's lawlessness as genuine, not as the allegations of political rivals that Pericles suffered from at the end of his life. Similarly, he attributes Alcibiades's every action to the guiding force of an overwhelming ambition, making him at least resemble an aspiring target. While the Athenians' distrust had tragic consequences, these consequences flow in part from the mistake of putting the war policy in his hands to begin with.

For Hobbes, however, Alcibiades's downfall stems largely from demotic envy of his genuine greatness:

For most men fearing him, both for his excess in things that concerned his person and form of life and for the greatness of his spirit in every particular action he undertook, as one that aspired to the tyranny, they became his enemy. And although for the public he excellently managed the war, yet every man, privately displeased with his course of life, gave the charge of the wars to others, and thereby not long after overthrew the state. $^{43}$

By splitting the overreach of Alcibiades's life into "excess" in his personal habits but genuine "greatness of spirit" in his public actions, Hobbes partly

${ }^{42}$ Thuc. 6.15.

${ }^{43}$ Hobbes, English Works: Thucydides, 6.15. 
delegitimizes the fear that Alcibiades secretly craved tyranny. The rendering of dianoias as "greatness of spirit" further suggests a natural superiority that was borne out in Alcibiades's public acts, instead of a fundamental desire for superiority guiding Alcibiades's plans and decisions. ${ }^{44}$ In the next sentence, Hobbes alters the contrast between Alcibiades's actions in private (idiai) and on behalf of the people (dèmosiai), which offers a parallel with the causes of the Athenians' fear, to instead emphasize that the Athenians' dissatisfaction with Alcibiades stemmed from individuals' private, or insufficiently publicminded, judgments of his behavior. The Athenians are therefore largely to blame for alienating him, and in so doing, for the overthrow of the state. ${ }^{45}$

This is not to say that Hobbes uncritically endorses Alcibiades. His rendering of Alcibiades's various speeches echoes aspects of his rendering of Pericles's, as when Alcibiades defends his excessive expenditures on Olympic teams and the arts on the grounds that "to strangers this also is an argument of our greatness." ${ }^{\prime 6}$ Where Hobbes's Pericles called on Athenians to recognize the relationship between Athens's power and their own self-interest, his Alcibiades claims to perform the vital civic role of making Athens look powerful. But not only does this assessment imply that Athens's power is debatable (at the same time as Alcibiades calls for an incredibly ambitious and costly military adventure!), it highlights the extent to which Alcibiades's ambition is only accidentally connected to Athenian success. Similarly, where Pericles defended his wartime policies by appealing to collective interests, Alcibiades defends himself by chiding the Athenians for their envy and telling them that they will be proud of him after he dies.

Hobbes praises Alcibiades with faint damnation. He paints democratic political contestation with the broadest of brushes, condemning all Athenian political figures after Pericles as petty self-promoters whose policy disagreements are mere interpersonal squabbles. The wisest response to such a political degeneration and the threats that it poses to competent potential leaders is the response Hobbes attributes to Thucydides: engage in politics only as one is obligated, and quietly write history and political advice instead. Someone with Alcibiades's ambitions, however, could not accept such a withdrawal. Instead, Hobbes portrays Alcibiades as having learned all the lessons from Pericles that his ambition could permit.

\footnotetext{
${ }^{44}$ Cf. Mynott ("ambitions"); Hammond ("huge ambition"). Even Jowett, who often follows Hobbes quite closely, renders dianoias as "far-reaching purposes." Compare also Aristotle's virtue of "greatness of soul" (megalopsuchia).

${ }^{45}$ C. D. C. Reeve, "Alcibiades and the Politics of Rumor in Thucydides," Philosophic Exchange 42, no. 1 (2011): 8-11, argues for a reading of Alcibiades very similar to the one I attribute to Hobbes. Steven Forde, The Ambition to Rule (Ithaca, NY: Cornell University Press, 1989), 72-75, takes Thucydides as at least somewhat sympathetic to Alcibiades in that Alcibiades's character and talents offered Athens its best chance at victory later in the war.

${ }^{46}$ Hobbes, English Works: Thucydides, 6.16.
} 
Hobbes's Alcibiades understands the extent of the backbiting, envy, and mistrust to be directed at anyone of his talents, as well as the overall degeneration of Athenian politics. As a result, Hobbes's Alcibiades presents a different and more cynical version of calculative self-interest, along with a series of characteristically Hobbesian psychological insights.

Alcibiades's unexpected Hobbesian insights are particularly evident in his speech to the Spartans explaining why they should accept him as a useful adviser because-not in spite-of his willingness to betray Athens. His sharp and elegant synthesis of fear and reason, and his sweeping redefinition of the love of one's city, deserve particular attention. The first of these, found in his strategic advice to the Spartans, connects Hobbes's presentation of Periclean calculation with his later direct appeal to fear in Leviathan and elsewhere. According to Hobbes's Alcibiades, the Spartans should invade and fortify a key location in Attica because this tactic is "a thing which the Athenians themselves most fear, and reckon for the only evil they have not yet tasted in this war. And the way to hurt an enemy most is to know certainly what he most feareth and to bring the same upon him. For in reason a man therefore feareth a thing most as having the precisest knowledge of what will most hurt him." ${ }^{\prime 7}$ This claim involves translational moves of the kind we have seen already and a broad and characteristically Hobbesian psychological claim. The renderings of saphōs (generally "clearly" or "distinctly") as "certainly" and of punthanomenos ("learning" or "finding out") as "to know" tend toward a tone of epistemic certainty that matches Hobbes's later intellectual tendencies. They also have the rhetorical function of emphasizing Alcibiades's authority as a strategist and informant, because only a high-ranking Athenian defector could claim "to know certainly" the Athenians' greatest fears. In the same way that Hobbes's Pericles establishes a relationship of epistemic sovereignty over the ekklesia, Hobbes's Alcibiades sets himself up as authoritative over his Spartan listeners.

The deeper connection between fear and knowledge or reason is also worth examining. Alcibiades's argument for the value of his inside information can be read in a fairly minimalist sense of psychological warfare: exploiting an enemy's fears in some way is likely to accomplish more than the direct material results of the attack would otherwise have done. Here, the psychological value of fear is doing all the work for Alcibiades-inflicting the Athenians' worst fears on them will be useful because it would be terrifying, and therefore hurt the Athenians more than if they simply calculated the damage caused by another Peloponnesian incursion into Attica. The connection between fear and strategy is a negative one; exploiting an enemy's fears is the surest way to cause harm because the enemies know their own fears,

\footnotetext{
${ }^{47}$ Hobbes, English Works: Thucydides, 6.91. Mynott: “The surest way to hurt your enemies is to identify clearly the things they most dread and then inflict those on them, since naturally everyone knows precisely what their own worst terrors are and fears them accordingly."
} 
while they may not know what their true strategic weaknesses are. Alcibiades, on this rendering, may well be mobilizing the Spartan perception of Athenian politics as unwise, overreaching, and prone to departures from well-informed strategic thinking.

Hobbes, however, has Alcibiades taking Athenian fear as strategically valuable instead of as psychologically valuable, and therefore has Alcibiades suggesting that fear reflects one's actual knowledge. Knowing an enemy's worst fear is "the way to hurt an enemy most" - not the "surest" way, as most other translators render it-because the enemy has private knowledge of what is actually harmful to them and their fears reflect this knowledge. Alcibiades's insight is valuable to the Spartans because it makes this private knowledge indirectly available. Hobbes further reinforces this move toward reading fear as rational when he renders eikos ("naturally" for Mynott), which generally identifies an assertion as plausible, as "in reason," implying that rather than being merely reasonable (permitted by reason), the connection between knowledge and fear is required by reason. Alcibiades's psychological argument contains implicit premises that Hobbes would later explicitly defend in Leviathan, along with the argument that costs and benefits are necessarily subjective, such that one's perception and fear of harm are not only private, but correct by definition.

Alcibiades's discussion of the love of one's city (philopolis), in Hobbes's rendering, is less a redefinition of Pericles's call for public sacrifice than a restatement of the commitment to calculative self-interest that Hobbes attributes to both Pericles and Alcibiades. Alcibiades offers two main defenses for his trustworthiness, asking his audience neither to consider him a traitor nor to mistrust him as a fugitive. First, he argues that he cannot be blamed for having fled to Sparta, because the blame falls on "the malice of them that drave me out." ${ }^{48}$ The Spartans and their allies, in a moment of intense sophistry, are not Athens's worst enemies - the Peloponnesians "have hurt but your enemies," while the Athenians who drove Alcibiades out "made enemies of friends" and therefore have become their own worst enemies. Second, Alcibiades contends, it will not do to condemn him for a lack of patriotism simply because he intends to help the Spartans "pull down the power of the Athenians both present and to come." Instead, he says that his behavior demonstrates his genuine love for Athens: "I love not my country as wronged by it, but as having lived in safety in it. Nor do I think that I do herein go against any country of mine, but that I far rather seek to recover the country I have not. And he is truly a lover of his country not that refuseth to invade the country he hath wrongfully lost, but that desires [epithumein] so much to be in it as by any means he can he will attempt to recover it." ${ }^{49}$ Alcibiades's redefinition of the love of one's city, read today, resembles nothing quite as much as a larger-than-life version of a homicidal stalker, in

${ }^{48}$ Hobbes, English Works: Thucydides, 6.92.
${ }^{49}$ Hobbes, English Works: Thucydides, 6.92. 
large part because his willingness to destroy the city if he cannot have it displays exactly those characteristics. ${ }^{50}$

Most translations reinforce this reading by emphasizing the political aspects of what Alcibiades lost: Alcibiades loves that he "once enjoyed the privileges of a citizen" (Jowett) or even that he "was secure in [his] role as a citizen" (Mynott), and indeed the phrase all' en hōi asphalōs epoliteuthēn strongly suggests that citizenship and the consequent potential for rulership are crucial in Alcibiades's calculus. Having been rejected by the city on account of his disposition toward tyranny, Alcibiades seeks to guide the Peloponnesians to victory, reduce Athens to servitude, and take his place as the newly installed tyrant of Athens. However, Hobbes plays up Alcibiades's claimed defensive motivations. Alcibiades valued life in Athens because he had "lived in safety," erasing the political connotations of a verb (politeuomai) that invariably denotes living politically. As a result, what is "lost" to him when he fled prosecution is less his chances of ruling Athens than the home that he genuinely tried to defend. In Hobbes's rendering, Alcibiades may have had a tragic or self-destructive conception of his selfinterest, but his apologia to the Spartans shows the consequences of political circumstances that divorce the self-interest of people like Alcibiades from the well-being of the polity they inhabit.

\section{Hobbes's Rhetorical Model and Its Significance}

A strategy of modeling a less conflict-producing, more stable rhetorical practice through translation is far less direct than the styles and methods Hobbes would later adopt. Nonetheless, the commitments that guided Hobbes in the renderings he selected for this translation are surprisingly consistent with those he expressed in the 1640s and 1650s. The concept of fear as a uniquely rational affect, the commitment to encouraging calculative self-interest in order to restrain ambition and glory-seeking behavior, and a tendency to blame civil conflict on the competitive and powerful few all appear in The Elements of Law, Leviathan, and Behemoth. Both the differences in intellectual and persuasive method and the continuities between the commitments that guided these texts offer valuable insights into the treatment of rhetoric in Hobbes's work. More broadly, the diversity of Hobbes's methods and the consistency of his attack on "rhetoric" as a political practice expose tensions within the modern project of divorcing "public reason" from other sorts of rhetorical appeals.

Hobbes's use of the translation, and especially of the figure of Pericles, offers an underappreciated approach to resolving the tension between the use and condemnation of eloquence in early modern political thought.

\footnotetext{
${ }^{50}$ Jowett's gloss on this passage conveys exactly this sense, but without any hint of irony.
} 
First, by displaying the damage that eloquent glory-seekers could do even in a relatively homogeneous ancient democracy, the translation warned of the still greater dangers of unconstrained rhetoric in a modern, increasingly plural commonwealth. Second, the sovereign figures standing above the bickering demagogues of Hobbes's Thucydides suggest a response to the problems of plurality: uniting the diverse interests and concerns of citizens under the education and power of a sovereign ruler. Third, however, without the discursive and material resources from which later modern critics of "rhetoric" benefited, the translation's project of distinguishing between rhetoric in the service of sovereignty and rhetoric that dislocates the joints of the body politic reveals the rhetorical dimensions of such a distinction.

The danger that rhetoric poses to the commonwealth, as seen in the first section of this article, looms over Hobbes's prefatory comments to the translation. I have quoted Hobbes's much later statement, in his prose autobiography, that he "decided to translate [Thucydides], in order to make him speak to the English about the need to avoid the rhetoricians whom they were at that time planning to consult." ${ }^{51}$ At the beginning of the article, this quotation signaled the extent to which Hobbes recognized the political nature of this intervention; here, it signals the intervention's urgency. The opportunities for Hobbes's contemporaries to manufacture controversies to suit their own ends were, if anything, considerably broader and more frequent than those available to Thucydides's contemporaries. While political prosecutions for "impiety" were not unknown to ancient Athens, the religious aspects of civil and interstate conflict in seventeenth-century Europe have no adequate parallel in Thucydides's time. ${ }^{52}$ Other causes of conflict, if familiar to Thucydides and his contemporaries, were nevertheless exacerbated through the increased size and complexity of the rising nation-state, increased literacy, the printing press, and similar factors. Hobbes would, in his mature political thought, conclude that the plurality of interests and conceptions of the good meant that the only interest that truly unites humans is the avoidance of violent death. Rhetoric, as a practice of connecting listeners' interests and commitments to create a new and contingent solidarity, threatened to empower conflicting factions. In providing a classical portrait of the dangers of rhetoricians and factional conflict, Hobbes's Thucydides translation was an attempt to forestall this threat.

${ }^{51}$ Skinner, Reason and Rhetoric, 230. Steinmetz, "Hobbes and the Politics of Translation," 6-7, offers an excellent analysis of a similar statement in Hobbes's verse autobiography, as well as of similar implications in the Thucydides translation's frontispiece.

${ }^{52}$ The obvious example, in this context, is the prosecution of Alcibiades, but the phenomenon was rather broader and continued for many years. See L.-L. O'Sullivan, "Athenian Impiety Trials in the Late Fourth Century B.C.," Classical Quarterly 47, no. 1 (1997): 136-52, for a survey of the later proliferation of politically motivated impiety prosecutions. 
The sovereign figure of Pericles, and the flawed but decidedly Hobbesian figure of Alcibiades, also provide important continuities between Hobbes's Thucydides and the later philosophical treatises. In each case, Hobbes relies on an authoritative figure to provide unity and overcome divisions in the body politic. In the case of the translation, however, the rhetorical appeal to accept sovereign authority comes from the mouth of a sovereign figure rather than from Hobbes, a mere philosophical counselor. Pericles's education of the Athenians not only directs the reader to cultivate the ability to calculate self-interest and warns against accepting the advice of parliamentary rhetoricians, but also offers an image of what a Hobbesian monarch could accomplish - not to mention the reminder that such a ruler could offer even more, without having to worry about backbiting from people like Cleon. And at the same time, the figure of Hobbes's Alcibiades warns that in a less stable political environment, the most gifted of citizens are forced to become dangerous. This combination of calculative self-interest and correctly calibrated fear, channeled through the authority of a sovereign political figure, was further reinforced by Hobbes's emphasis on the value of Pericles and repeated instructions to the readers to learn from the translation in the prefatory notes. Hobbes sets readers up to learn from him without, at this point, taking credit for teaching them. Much like a subject that, as a member of the Leviathan, has access to the principles and definitions that enable correct reasoning, the reader is enabled to reason correctly from the evidence that Hobbes provides in the translation.

But what makes this reasoning correct? The attempt to persuade readers to accept an authoritative standard and reject orators' appeals to do otherwise is, of course, hardly unique to Hobbes. Recent literature on early modern political thought has emphasized the rhetorical dimensions of early modern authors' political interventions. Torrey Shanks's argument for the influence of Epicurean materialism on Locke's political thought, and consequently for a deep commitment to persuasion and rhetoric "as figural and creative language," is particularly exemplary. ${ }^{53}$ Shanks's reading of Locke grounds a crucial distinction between rhetoric as it was used by early modern political thinkers and how it was talked about by the same thinkers. Other scholars have directed new attention to the role of rhetoric in the work of Immanuel Kant. ${ }^{54}$ Far more than in the past, scholars recognize the concern for

\footnotetext{
${ }^{53}$ Shanks, Authority Figures: Rhetoric and Experience in John Locke's Political Thought (University Park: Pennsylvania State University Press, 2014), ix.

${ }^{54}$ On the role of rhetoric in Kant's work, Scott Stroud, Kant and the Promise of Rhetoric (University Park: Pennsylvania State University Press, 2014), is one of the most extensive and generative revisionist readings. See also Stroud, "Kant, Rhetoric, and the Challenges of Freedom," Advances in the History of Rhetoric 18 (2015): 181-94, https://doi.org/10.1080/15362426.2015.1081528; Michael Clarke, "Kant's Rhetoric of Enlightenment," Review of Politics 59, no.1 (1997): 53-74, https://doi.org/10.1017/ S0034670500027157; Don Paul Abbott, "Kant, Theremin, and the Morality of
} 
persuasion within the political appeals these authors crafted. But there is an important difference between how political actors use rhetoric and how they theorize rhetoric, and if someone theorizes rhetoric as a set of harmful or dangerous practices while carefully writing persuasive appeals, this is worth further investigation. For Locke and Kant, and for some of their successors, one might explain this by saying that Locke's characterization of rhetoric as "a powerful instrument of error and deceit," or Immanuel Kant's as "the art of using the weakness of people for one's own purposes," reflect a set of concerns about a specific mode of persuasion that can be avoided while remaining attentive to style, clarity, and persuasion. ${ }^{55}$ But the rhetoric of Leviathan, as well as of some of the sharper passages in the Elements of Law, does not fit with these concerns. ${ }^{56}$

The rhetoric of Hobbes's Thucydides, even if its essential components work through sovereign figures, functions primarily as an attempt to remove resources for those who would defend robust political contestation and persuasive practices that compete with those Hobbes endorses. In this way, it is analogous to Hobbes's move to put competing perspectives into the mouth of "the Foole" or into the category of "absurditie" in Leviathan, and to later theorists' creating sharp distinctions between rationalistic projects and "rhetoric" and relegating the latter to the realm of deceit and manipulation. Each of these moves attempts to make the favored mode of persuasion natural and universal by excluding alternatives from consideration, and does so without closely engaging those alternatives on their own terms. If later theorists' exclusion of alternative possibilities, without so engaging them, seems more self-contained, perhaps they found this project easier when building on efforts like Hobbes's. 57

Hobbes had to accomplish a similar task with fewer cultural and intellectual resources. For his Thucydides, he did not even have geometry to fall back on. The tenuous and contingent aspects of his rhetorical appeal to sovereignty show through. The attempt to rhetorically distinguish between sovereign authority and "rhetoric" appeals not to geometric proofs, "right reason," or the laws of nature and nature's god, but to the rhetoric of a first

Rhetoric," Philosophy and Rhetoric 40, no. 3 (2007): 274-92, https://www.jstor.org/stable/ 25655277.

${ }^{55}$ Hobbes, Leviathan, ed. Curley, 25. John Locke, An Essay concerning Human Understanding (London: Otridge, 1812), 2:42. Immanuel Kant, Critique of the Power of Judgment, ed. and trans. Paul Guyer (Cambridge: Cambridge University Press, 2000), 205.

${ }^{56}$ On the moments of sharp polemical rhetoric in the Elements, see Miller, Mortal Gods, 126-30.

${ }^{57}$ Felix Waldmann has recently uncovered evidence of a much greater Hobbesian influence on Locke than was previously recognized. Waldmann, "John Locke as a Reader of Thomas Hobbes's Leviathan: A New Manuscript," Journal of Modern History 93, no. 2 (June 2021): 245-82. 
citizen whose leadership ended in failure and grief. As a result, a tragic note sounds through the translation's political intervention. It warns of the consequences of rejecting sovereign authority and embracing rhetoricians' appeals, but where the theoretical artifice of Leviathan and the legalistic and rationalistic appeals of Hobbes's successors build mutually exclusive monuments to a universal and rigid political order, Hobbes's Thucydides offers only the fragile and ultimately fallen figures of a lonely statesman and his terribly brilliant, terribly flawed following act.

This earliest attempt to marginalize rhetorical appeals occurring within a sovereign political order prefigures a characteristic pattern of such projects, in which contestation at the margins tended to become struggles over first principles, and rhetoric therefore did the ground-up work of constituting a new solidarity or public capable of protecting itself from its foes. Instead of excluding rhetoric from a stable political order, Hobbes's project pushed rhetoric toward the revolutionary fringe. Hobbes's Thucydides inaugurated an early modern project to poison the well of rhetoric, persuading generations of political philosophers and statesmen that rhetoric as Hobbes's predecessors understood it was fundamentally misleading, pernicious, and productive of conflict. But neither Hobbes nor his successors nor the politicians that became their students could stop returning to the well. 